\title{
THE EFFECT OF USING INTERACTIVE GUESSING GAME TECHNIQUE ON FLUENCY STUDENT'S SPEAKING SKILL
}

\author{
Zully Zulaikho Puspitasari ${ }^{1}$, Slamet Asari ${ }^{2}$ \\ University of Muhammadiyah Gresik ${ }^{1}$ \\ zullypus12@gmail.com
}

\begin{abstract}
Abstrack
This article explains the result of research that aim to test whether using interactive guessing game technique give significant effect on fluency student's speaking skill in short functional text of MTs. Bustanul Ulum Tanggungprigel. This research uses a quasi experimental research design. The population of this research was the VIII grade students of MTs. Bustanul Ulum Tanggungprigel. There were two classess that totalized 50 students. The sample of this research was VIII A and VIII B. The sample was selected by population sampling technique. The instruments were speaking test. The data were analyzed by independent sample t-test formula. The result of this research were the implementation of using interactive guessing game was significant to improve fluency student's speaking skill. It can be conclude that interactive guessing game technique gave significant effect toward fluecny student's speaking skill at MTs. Bustanul Ulum Tanggungprigel.
\end{abstract}

Keywords: interactive guessing game, fluency, speaking skill

\begin{abstract}
Abstrak
Artikel ini menjelaskan tentang hasil penelitian yang bertujuan untuk menguji apakah penggunaan teknik permaian tebakan interaktif membawa pengaruh yang signifikan terhadap kefasihan kemampuan berbicara dalam teks sederhana di MTs Bustanul Ulum Tanggungprigel. Penelitian ini menerapkan desain penelitian eksperimental kuasi. Populasi penelitian ini adalah siswa kelas 8 di MTs Bustanul Ulum Tanggungprigel. Terdapat 2 kelas dengan total 50 siswa. Sample dalam penelitian ini adalah kelas VIII A dan VIII B. Sample dipilih berdasarkan teknik sample dalam populasi dengan instrumen tes berbicara. Data yang terkumpul dianalisa dengan uji t mandiri. Hasil dari penelitian ini adalah penggunaan permainan tebak interaktif secara signifikan mempengaruhi kemampuan siswa dalam berbicara. Bisa disimpulkan bahwa teknik permainan tebak interaktif memberikan pengaruh signifikan terhadap kemampuan berbicara siswa di MTs Bustanul Ulum Tanggungprigel.
\end{abstract}

Kata Kunci: permainan tebak interaktif, kefasihan, kemampuan berbicara 


\section{INTRODUCTION}

Speaking is the process of communication or interaction with other people in order to communicate each other. Through communication, people can access the information and have a good relation in daily life. Thornbury (2007:1) states "Speaking is so much a part of daily life that we take it to granted." It means, by speaking people can express their ideas and purpose orally to the listeners. Because of that, learning speaking of foreign languages need more practice. On the other hand, speaking skill is one of language skills that must be mastered by any foreign language learner. English speaking skill also very prominent for the students because English speaking skill is very needed in global communication at the world. As we know that English used as an international language, it becomes the reason why people is competing to master English as communication tool in this globalization era. Good speaking activities should be extremely engaging for the students (Harmer, 2007:123). In teaching speaking, the teacher must be able to make interesting topic and apply the suitable technique. The aims are to make the students more interested and also to avoid boredom in learning English.

There are many problems in learning speaking skill (Buzanni, 2008): (1) the limited opportunities for the students to speak in class, (2) the lack of variation of teaching techniques used by the teacher in class, (3) the teaching strategy application was monotonous that made the students bored and disinterested in studying English. Considering those problems, one of techniques that teacher can apply in teaching speaking is through game, because game is one of potential activity that can be used as an alternative way to make better condition in the class in order that students do not feel bored and are interested to learn the meterial given by the teacher. In line with the statement, Chandra (2008) states that games are also believed to give positive effect on students' interest and motivation in studying English as well as to increase their speaking ability. So, the researcher is going to use an alternative technique in teaching speaking by using guessing 
game technique, in which students are expected to be involved actively in speaking class.

Guessing game is one kind of game in which the participants compete individually or in teams to identify something that indicate

obscurely (Wright, 2005:169). According to Klippel (1994), "Everybody knows guessing games, it is not only children that like guessing games; adult like guessing too, as shown by many popular TV programmer." He adds "Guessing are true communicative situation and such are very important to practice foreign language with fun and excitement." The basic rule of guessing games is very simple; one person knows something that another one wants to find out.

Based on the definition above, it can be said that through guessing game, students are provided by a set of well-arranged activities as follows: participates compete individually or team in identification of something object's picture is shown by the chairperson. In addition, the chairperson tells a clue to team that the object is household tools, clothes, vehicle or other stuff. On finding the answer of what object is team should ask yes or no question to the chairperson, for instance "is it water transportation?". Therefore, the chairperson is allowed only say 'yes' or 'no'. The team will get point if they can guess the answer by having not more than twenty questions.

There are some studies have investigate related with the implementation of guessing game technique on students' speaking skill. The first study conducted by Nita Herliani (2013) entitle "The Use of Guessing Game to Improve Student's Speaking Skill". The design is using both qualitative and quantitative approach. Qualitative data obtain through interview and observation. While, quantitative data will collect through speaking test. The aim is to find out the advantages and disadvantages of guessing game on student's speaking skill in order to improve teaching and learning process. Nita's study is not complete yet because in her study does not show the result of test. So, the reader did not know whether it can improve student's speaking skill or not. The second previous study is by Safitri, Bambang Wijaya, and Syarif Husin (2014) entitle "The Effectiveness of 
Guessing Game Towards Students'

Writing Skill on Descriptive Text".

The design is using quantitative

research and the aim is to investigate

the effectiveness and the effect of

using guessing game in students'

writing on descriptive text. The result

showed that the use of guessing

game significantly improves

students' mastery on writing

descriptive text, because the mean

score of post-test is better than the

mean score of pre-test. But,

suggestions of their research that is

to apply guessing game in other

skills in other genres. So, the

researcher here will conduct this

study using guessing game technique

in speaking skill with different

genres. The third previous study by

Rofi Robiah (2015) entitle "The Use

of Guessing Game to Improve Fourth

and Fifth Grade Students' Speaking

Ability of Elementary School Ar-

Rahman Anusorn Narathiwat

Southern Thailand 2014-2015

Academic Year". The design is using

Classroom Action Research Design

(CAR). The result and discussion

showed that guessing games provide

opportunity to formulate the question

on order to force the students to

speak. Through guessing game, student's speaking ability can improve.

The researcher does this study according to the previous study by Amelia Resti, Erni, and Mahsyur (2016) entitle "The Effectiveness of Guessing Game Technique in Improving Students' Speaking Ability at MTs. Hasanah Pekanbaru”. The design is using quantitative design. The aim was to find out the improvement of students' speaking ability through Guessing Game technique at MTs. Hasanah and to find out the effectiveness of guessing game technique in improving students' speaking ability. In the previous research, the highest score increased in speaking aspect is in comprehension. Meanwhile, the lowest score is in fluency aspect. It is because of the implementation of Guessing Game technique is using teacher center. So, the teacher emphasize more by asking students some questions relating with an object and also giving clues to the student, then the students only guess the object. Finally, the result showed that theory of Guessing Game is sigficant for comprehension aspect. Because students can comprehend what teacher said and guess an object 
by comprehending the clues from the teacher. So, the students get high score in comprehension aspect but not in fluency aspect. Whereas, fluency aspect is also important as comprehension aspect in speaking skill. Because fluency means speaking easily, reasonalbly, quickly and without having to stop and pause a lot. It is automatically in our brain, we have many vocabularies and accustomed to use English language in daily communication. So that, we can speak up fluently. But, in comprehension aspect make students passive speaking because they only answering the clues that given by the teacher. It means, they are not communicate each other. There is no interaction among students in the class. So that is why, the researcher will do this research again, because she want to increase students' speaking skill especially in fluency aspect with different steps using Guessing Game technique.

The researcher here wants to change name from Guessing Game become Interactive Guessing Game technique in order to different with other studies. Interactive itself means there is an action and communication between two people or two thing such as two-way communication. The researcher add the word interactive because there is communication and interaction between student who gives clues in front of the class and other group who should guess the clues. So, that is why she want to rename the name.

Based on the statements above, the researcher assumes that applying guessing game technique is effective toward the students' speaking skill because it gives students more chance to practice and gives more opportunities to the students to make turn in speaking during the times allocated. The researcher tought that games are combination between language and fun. The students can practice and express their idea freely because they do activities with their friends. The researcher wants to know whether the use of game is effective or not in teaching speaking. So, the researcher is interested to conduct research to see the effectiveness of using guessing game technique toward the eight grade fluency students' speaking skill at MTs. Bustanul Ulum Tanggungprigel.

\section{METHOD}


This article retrieved from the research on the effect of using interactive guessing game technique on fluency student's speaking skill at MTs. Bustanul Ulum Tanggungprigel. The design of this research was a quasi experimental research design. Experimental is a form of quantitative research. It compared the result of two researchers group. According to Gay (2000) experimental research is the only type of research that can test hypotheses to establish cause andeffect relationships.

The population of this research was the second grade of MTs. Bustanul Ulum Tanggungprigel. the researcher used population sampling technique to determine the sample of this

research. Population sampling technique used if the total of population is used as sample. Before it was selected, the researcher analyzed the homogeneity and normality of population. Class VIII A was selected as experimental group which taught by using interactive guessing game technique while class VIII B was selected as control group which taught by using two stay two stray.
In this research, the data were collected by using test of speaking skill. There are pre and post test. But before conducting the test, the researcher do validity in order to know whether the test is valid or not. Here the researcher use content validity to verify the validity of pre test and pot test that will be given to the students. For testing the content validity the researcher compares the instrument content to the subject basic on curriculum and syllabus of Junior High School. If the test content appropriate with the curriculum guides, syllabus, and course books, it means the test have content validity and the test item can give to the students.

The test is aimed to know the students' speaking skill especially in the fluency aspect through teaching speaking by using interactive guessing game technique. The test which given was giving instruction to the students. The students were asked to deliver short functional text that include short message, announcement and notice orally. Test used to measure student's speaking skill in short functional text. It was arranged based on the indicators of 
speaking for short message as follow:

Table 2. List of speaking test indicators

\begin{tabular}{|c|c|c|c|c|c|}
\hline \multirow[b]{2}{*}{ No } & \multirow[b]{2}{*}{ Criteria } & \multicolumn{4}{|c|}{$\begin{array}{l}\text { Rating Scale } \\
\end{array}$} \\
\hline & & $\begin{array}{c}\text { Poor } \\
1\end{array}$ & $\begin{array}{c}\text { Fair } \\
2\end{array}$ & \begin{tabular}{|c|} 
Good \\
$\mathbf{3}$ \\
\end{tabular} & $\begin{array}{c}\text { Excellent } \\
4\end{array}$ \\
\hline 1. & Fluency & $\begin{array}{l}\text { Students } \\
\text { hesitant too } \\
\text { often when } \\
\text { speak which } \\
\text { interfere } \\
\text { communication }\end{array}$ & $\begin{array}{l}\text { Students speak } \\
\text { with some } \\
\text { hesitant with } \\
\text { often interfere } \\
\text { communication }\end{array}$ & $\begin{array}{l}\text { Students speak } \\
\text { with some } \\
\text { hesitant but it } \\
\text { does not really } \\
\text { interfere } \\
\text { communication }\end{array}$ & $\begin{array}{l}\text { Students speak } \\
\text { bravely and } \\
\text { clearly with } \\
\text { little hesitant } \\
\text { that does not } \\
\text { interfere } \\
\text { communication }\end{array}$ \\
\hline 2. & Pronunciation & $\begin{array}{l}\text { There are an } \\
\text { error with more } \\
\text { than } 15 \\
\text { pronunciation }\end{array}$ & $\begin{array}{l}\text { There are an } \\
\text { error with } 10-12 \\
\text { pronunciation }\end{array}$ & \begin{tabular}{|l} 
There are an \\
error with 6-8 \\
pronunciation
\end{tabular} & $\begin{array}{l}\text { There are an } \\
\text { error with 3-5 } \\
\text { pronunciation }\end{array}$ \\
\hline 3. & Content & $\begin{array}{l}\text { The content } \\
\text { does not match } \\
\text { at all with the } \\
\text { theme which is } \\
\text { chosen by the } \\
\text { teacher and } \\
\text { forget to } \\
\text { arrange the } \\
\text { content with } \\
\text { the generic } \\
\text { structure }\end{array}$ & $\begin{array}{l}\text { The content is } \\
\text { little bit match } \\
\text { with the theme } \\
\text { which is chosen } \\
\text { by the teacher } \\
\text { and arrange the } \\
\text { content with the } \\
\text { generic structure } \\
\text { but not well } \\
\text { organize }\end{array}$ & $\begin{array}{l}\text { The content is } \\
\text { match with the } \\
\text { theme which is } \\
\text { chosen by the } \\
\text { teacher and } \\
\text { arrange the } \\
\text { content with the } \\
\text { generic structure } \\
\text { but nor well } \\
\text { organize }\end{array}$ & $\begin{array}{l}\text { The content is } \\
\text { match with the } \\
\text { theme which is } \\
\text { chosen by the } \\
\text { teacher and the } \\
\text { generic structure } \\
\text { is well organize }\end{array}$ \\
\hline 4. & Vocabulary & $\begin{array}{l}\text { Able to use } \\
\text { more than } 5 \\
\text { words }\end{array}$ & $\begin{array}{l}\text { Able to use } \\
\text { more than } 10 \\
\text { words }\end{array}$ & $\begin{array}{l}\text { Able to use } \\
\text { more than } 15 \\
\text { words }\end{array}$ & $\begin{array}{l}\text { Able to use } \\
\text { moreh than } 20 \\
\text { words }\end{array}$ \\
\hline 5 . & Comprehension & $\begin{array}{l}\text { Delivering } \\
\text { short functional } \\
\text { text with } \\
\text { limited } \\
\text { understanding } \\
\text { of content }\end{array}$ & $\begin{array}{l}\text { Delivering short } \\
\text { functional text } \\
\text { with some } \\
\text { understanding of } \\
\text { content }\end{array}$ & $\begin{array}{l}\text { Delivering } \\
\text { monologue with } \\
\text { many } \\
\text { understanding of } \\
\text { content }\end{array}$ & $\begin{array}{l}\text { Delivering } \\
\text { monologue with } \\
\text { full } \\
\text { understanding of } \\
\text { content. There is } \\
\text { no repetition } \\
\text { and full of } \\
\text { rephrasing } \\
\end{array}$ \\
\hline
\end{tabular}

After conducting pre and post test, the next step is analyzing the data. The researcher analyzes the data by using independent sample ttest in SPSS version 16.0. Since the samples are small and the groups are independent, the t-test for independent samples is carried out to determine whether there is any difference between experiment and control group.

\section{DISCUSSION}

Based on data analysis, the result in conducting this research found that the implementation of 
interactive guessing game technique was effective to improve the students' speaking skill. It can be proved with the result of post test for experimental group was higher than control group which was 81.8800 while control group was 80.2400. Besides, the result showed that the value of sig.(2-tailed) was 0.028 , it means the significant value is less than 5\%. So, the null hypothesis could be rejected. While for the students' speaking skill score in the fluency aspect of pre test also higher than in the post test. It can be conclude that there was significant effect of using interactive guessing game technique at eight grade students of MTs. bustanul Ulum Tanggungprigel. The result showed that it is appropriate with the expectation.

This research is different with other research, because in this research the researcher change the name "guessing game" became

"interactive guessing game technique". This game is interactive game because there is an interaction among the students and also the teacher. There are some kinds of guessing game such as; i-spy, twenty questions, coffe-pot, and guess word game. The researcher here want to use one kind of game that is twenty questions game. This twenty questions game is never use before in doing the research. It is only a game that apply in the classroom to give the students ice breaking but not to do the research. So that, here the researcher want to use it to know whether the use of this game can give significant effect on students' speaking skill or not especially in the fluency aspect. In the previous study not using this game and there is no interaction among the students, it is because of the researcher using teacher center when teaching in the classroom while for this study, the researcher using students center.

After conducting this study about the effectiveness of using interactive guessing game technique in students' speaking ability, we know that interactive guessing game technique can improve their speaking ability. Because in interactive guessing game technique can make the students build their confidence to speak in English. This does not only give benefits to the students but also the teacher who makes the class more attractive and not monotonous. 


\section{CONCLUSION}

This study tried to investigate the effects of interactive guessing game technique towards the eight grade students of MTs. Bustanul Ulum Tanggungprigel on fluency speaking skill. One group pre-test and post-test design was used and the result showed that the students in interactive guessing game technique had positively $(p<0.05)$. In the other words, using interactive guessing game technique proved to be better, more efficient and effective for teaching speaking to the eight grade

of MTs. Bustanul Ulum Tanggungprigel. Besides, using interactive guessing game technique can improved the students' speaking skill especially for fluency aspect. So, for improving students' speaking skill score especially in fluency aspect it is recommended to use interactive guessing game because this game gives students more change to practice and gives more opportunities to make turn is speaking when the students try to guess something.

\section{REFERENCES}

Amir, F. (2010). The Use of

Guessing Game to Improve

Student's Speaking Skill.

Unpublished Master's Thesis.

Program Sarjana Universitas

Pendidikan Indonesia,

Bandung.

Ary, D. 2010. Introduction to Research in Education Eight. United State: Wadsworth.

Brown,H. D. 1994. Teaching by Principle: An Interactive

Approach Language

Pedagogy. Englewood Cliffs:

Prentice Hall. . 2001. Teaching by

Principles: An Interactive

Model to Language

Pedagogy, second edition.

New York: Pearson

Education Company. . 2004. Language Assessment: Principles and Classroom Practices.

London: Longman, Inc.

Burns, A. 1999. Collaborative Action

Research for English

Language Teachers. New

York: Cambridge University

Press.

Buzanni. (2008). The Use of Guessing Games in 
Improving Students' Speaking

Ability at the Second Year

Students Of MTS Ikhtiyarul

Ummah

Pamekasan.

Retrieved

from

http://historyofindonesi.blogs

pot.com/2013/07/

Creswell, J. W. 2012. Educational

Research: Planning,

Conducting, and Evaluating

Quantitative and Qualitative

Research (Revised Eds.).

Boston: Pearson Education,

Inc.

Dwi M, Mega. (2009). The Use of Guessing

Game in Teaching Speaking. Bandung:

Unpublished.

Dwiyanti. (2009). The Improvement

Students' Speaking Skill

Through Guessing Games

Technique. Retrieved from

http://www.scribd.com/doc/2

2057958/

Fitriana, D. (2012). Improving The

Speaking Skills Through

Guessing Games of The

Seventh Grade Students of

SMP Muhammadiyah 1

Seyegan Yogyakarta in The

Academic Year of

2012/2013. Unpublished

Master's Thesis. Program
Sarjana Universitas Negeri, Yogyakarta.

Harmer, J. 2007. How to Teach English. London: Longman.

Herliana, N. (2013). The Use of Guessing Game to Improve Student's Speaking Skill. Unpublished Master's Thesis. Program Sarjana Universitas Pendidikan Indonesia, Bandung.

Klippel, F. 1994. Keep Talking: Communicative fluency activities for language teaching. New York: Cambridge University Press.

Muijs, D. (2004). Doing Quantitative Research in Education. London: SAGE Publications Ltd.

Nunan, D. 2003. Practical English Language Teaching. NY: McGrawHill.

Richard, K., \& Willen. 1996. Dynamics of Effective Teaching. New York: Longman publishee USA.

Robiyah, R. (2015). The Use of Guessing Game to Improve Students' Speaking Ability. Journal of Education. Retrieved from 
https://digilib.unmuhjember.a

c.id/download.php

Spratt, M., Alan Pulverness and

Melanie Williams. (2005).

The TKT Teaching

Knowledge Test Course. New

York: Cambridge University

Press.

Sugiono. (2009). Metode Penelitian

Kualitatif dan Kuantitatif

$R \& D$. Bandung: Alfabeta.

Thornbury, S. 2007. How to Teach

Speaking. London: Longman Press.

Wright, A., Batteridge, D., \& Buckby, M.

2005. Games for Language

Learning (3 Edition). New York: 